\title{
Morphological Variations of Jugular Foramen in South Indian Dry Skull
}

\author{
Kandhal Yazhini. P1 ${ }^{1}$ Thenmozhi. M. S² and Yuvaraj Babu. K ${ }^{3 *}$ \\ ${ }^{1}$ Department of Anatomy Saveetha Dental College and Hospitals, Saveetha institute \\ of medical and technical sciences, Saveetha university, Chennai- 600077, India \\ ${ }^{2}$ Department of Anatomy, Saveetha Dental College \& Hospitals, Saveetha institute \\ of Medical and Technical Sciences, Saveetha University, Chennai- 600077, India \\ Department of Anatomy, Saveetha Dental College \& Hospitals, Saveetha institute \\ of Medical and Technical Sciences, Saveetha University, Chennai- 600077, India
}

\begin{abstract}
Jugular foramen lies between the occipital bone and the petrosal portion of the temporal bone in the posterior end of the petrosal-occipital structure, and it is long and irregularly shaped. It is the main route of venous outflow from the brain and passage for the lower three cranial nerves $(9,10$, and 11) from the skull. It is anteriorly separated from the internal carotid artery opening by a crest and separated from the hypoglossal canal through a thin bony bar. The anterior portion transmits inferior petrosal sinus and the intermediate portion or neural compartment transmits glossopharyngeal, vagus and accessory nerves and its posterior portion or vascular compartment includes the internal jugular vein and the meningeal branches of the ascending pharyngeal and occipital arteries. The aim of the study was to examine the morphological features and dimensions of Jugular Foramen in human adult dry South Indian skulls. The mean length on the right was $9.73 \mathrm{~mm}$ and on left was $9.12 \mathrm{~mm}$. The mean breadth of right and left jugular foramen are $13.07 \mathrm{~mm}$ and $12.28 \mathrm{~mm}$ respectively. From the above study it is evident that right jugular foramen is larger than that of left jugular foramen.
\end{abstract}

KEY WORDS: JUGULAR FORAMEN, AP DIAMETER, TRANSVERSE DIAMETER, SEPTUM.

\section{INTRODUCTION}

Jugular foramen is positioned between the petrosal portion of the temporal bone and occipital bone in the posterior end of the petrosal-occipital arrangement. It has a lengthy, amorphous shape (Daniels, Williams and Haughton, 1984; Ellis, 1989). It is the principal

\section{ARTICLE INFORMATION}

*Corresponding Author: yuvarajbabu@saveetha.com

Received 13th June 2020 Accepted after revision 9th August 2020

Print ISSN: 0974-6455 Online ISSN: 2321-4007 CODEN: BBRCBA

Thomson Reuters ISI Web of Science Clarivate Analytics USA and Crossref Indexed Journal

\section{Clarivate
Analytics}

NAAS Journal Score 2020 (4.31) SJIF: 2020 (7.728)

A Society of Science and Nature Publication,

Bhopal India 2020. All rights reserved.

Online Contents Available at: http//www.bbrc.in/

Doi: http://dx.doi.org/10.21786/bbrc/13.7/94 pathway of venous discharge from the brain. It is also the channel for the cranial nerves 9, 10, and 11 from the skull (Ekinci and Unur, 1997; Wysocki and Sharifi, 2006; Song et al., 2008). At the anterior it is separated from the internal carotid artery aperture by a concretion. It is also separated from the hypoglossal canal through a slim bone strut. The anterior portion carries on the inferior petrosal sinus. The glossopharyngeal, vagus and accessory nerves are transmitted by the intermediate portion or neural compartment. Lastly, its posterior portion, which is also called as the vascular compartment, includes the internal jugular vein and the meningeal branches of the ascending pharyngeal and occipital arteries (Katsuta, Rhoton and Matsushima, 1997). The glossopharyngeal, vagus and cranial part of the spinal accessory nerve goes through this and comes out of the cranial cavity. Jugular 
foramen has a lot of significance in surgical point of view (Tekdemir et al., 1998; Matsushima, 2015).

In 2004, Idowu concentrated on morphometric study on 20 dry skulls that is 40 jugular foramina of adult male nigerian population (Idowu, 2004). Vijisha et al.,2013 detailed that variety in the anatomy of intracranial venous sinus may be shown by the relationship of size and state of the jugular foramen with internal jugular vein and presence or absence of prominent superior jugular bulb (Vijisha, Bilodi and Lokeshmaran, 2013). Sushant Swaroop Das et al., 2016 has concentrated on gender difference along with morphometric study (Das, Saluja and Vasudeva, 2016). Ramina R et al .,2004 focused on jugular foramen tumors, diagnosis and treatment (Ramina et al., 2005). Aggarwal et al., 2012 provided the variations in the structure of jugular foramen in the northwest Indian population (Aggarwal et al., 2012). Anson has noted the depth of jugular foramen to range from $0-14 \mathrm{~mm}$ with most of the specimens less than $7 \mathrm{~mm}$ (Anson, 1972).

Previous articles analysed the anatomy of jugular foramen of a north eastern adult and various inter regional whereas our study focused on adult South Indian skull. The size, height and volume vary in different racial group and sex. The study was embarked on to examine the anatomy of the jugular foramen with dimensions of both right and left and also to check the partition. With a rich case bank established over 3 decades we have been able to publish extensively in our domain (Abdul Wahab et al., 2017; Eapen, Baig and Avinash, 2017; Patil et al., 2017; Jain and Nazar, 2018; J et al., 2018; Marimuthu et al., 2018; Wahab et al., 2018; Abhinav et al., 2019; Ramadorai, Ravi and Narayanan, 2019; Senthil Kumar et al., 2019; Sweta, Abhinav and Ramesh, 2019). Based on this inspiration we aim to examine the morphological features and dimensions of Jugular Foramen in human adult dry South Indian skulls.

\section{MATERIAL AND METHODS}

The examination of 30 human adult dry South Indian skulls was done in the Department of Anatomy of Saveetha Dental College and Hospital, Chennai.A digital vernier calliper was used to measure the dimensions of the following of both right and left Jugular Foramen.

- Antero-posterior diameter (mean length)

- Transverse diameter (mean breadth)

- presence(partial or complete septum)or absence of septum

The data was recorded and mean values were calculated. The right and left side differences were analyzed accordingly.

\section{RESULTS AND DISCUSSION}

The mean length on the right was $9.73 \mathrm{~mm}$ and on left was $9.12 \mathrm{~mm}$. The mean breadth of right and left jugular foramen are $13.07 \mathrm{~mm}$ and $12.28 \mathrm{~mm}$ respectively. The right jugular foramen was found out to be larger than the left jugular foramen. This size and shape of jugular foramen are related to the size of the internal jugular vein and presence or absence of a superior bulb. 23\% have complete septum, 46\% is partial and in $30 \%$ absence of septum. Variations in size, shape and compartment of jugular foramen might be a part of the ongoing evolutionary process. Knowledge of morphology ,compartment and arrangement of structures within the foramen helps in deducing position of various structures from the available data of jugular foramen depicted by the study.

Table 1. Mean breadth, length and occurrence of septum in right and left Jugular foramens

\begin{tabular}{|c|c|c|c|c|c|c|c|c|c|}
\hline \multicolumn{5}{|c|}{ LEFT JUGULAR FORAMEN } & \multicolumn{5}{|c|}{ RIGHT JUGULAR FORAMEN } \\
\hline \multirow{3}{*}{$\begin{array}{l}\text { Mean } \\
\text { length } \\
(\mathrm{mm})\end{array}$} & \multirow{3}{*}{$\begin{array}{c}\text { Mean } \\
\text { breadth } \\
(\mathrm{mm})\end{array}$} & \multicolumn{3}{|c|}{ Septum } & \multirow{3}{*}{$\begin{array}{c}\text { Mean } \\
\text { length } \\
(\mathrm{mm})\end{array}$} & \multirow{3}{*}{$\begin{array}{c}\text { Mean } \\
\text { breadth } \\
(\mathrm{mm})\end{array}$} & \multicolumn{3}{|c|}{ Septum } \\
\hline & & \multirow[t]{2}{*}{ Absent } & \multicolumn{2}{|c|}{ Present } & & & \multirow[t]{2}{*}{ Absent } & \multicolumn{2}{|c|}{ Present } \\
\hline & & & Partial & Complete & & & & Partial & Complete \\
\hline 9.73 & 12.28 & $30 \%$ & $46 \%$ & $23 \%$ & 9.21 & 13.07 & $26 \%$ & $54 \%$ & $23 \%$ \\
\hline
\end{tabular}

The mean length on the left was $9.73 \mathrm{~mm}$ and right was $9.21 \mathrm{~mm}$. The mean breadth on the right was $13.07 \mathrm{~mm}$. The mean breadth of left was $12.28 \mathrm{~mm}$. In left jugular foramen, 30\% of the skull doesn't contain any septum and $23 \%$ has a complete septum. In the right jugular foramen, 26\% doesn't have any septum, while 54\% has 
partial septum and 23\% has complete septum. From the above study it is evident that right jugular foramen is larger than that of left jugular foramen. This size and shape of jugular foramen is related to the size of the inter jugular vein and presence or absence of the superior bulb. From the above observation it is clear that complete septum is very rarely found and incomplete septum is the most prevalent.

A study conducted on these variations by lopes et al., states that the mean length of jugular foramen is $9.21 \pm 1.95 \mathrm{~mm}$ and $8.65 \pm 1.57 \mathrm{~mm}$. It mentions the mean length diameter to be $15.82 \pm 2.67 \mathrm{~mm}$ and $15.86 \pm 2.64 \mathrm{~mm}$ on right and left sides respectively in the southern Bracilian population (Lopes et al., 2011). As per sturrock, the right jugular foramen are larger in 69\% of skulls (Sturrock, 1988) whereas Hatibogle and Anil discover that $61.6 \%$ where larger on right and 26\% where larger on left (Hatiboglu and Anil, 1992). As per the studies conducted by Padget the difference in size of the internal jugular vein is visible in the human embryo as early as $23 \mathrm{~mm}$ stage. This is probably due to the difference in pattern of development of right and left brachiocephalic veins (Padget, 1957). As per the study conducted on srilankan skulls and AP diameter was $6.92 \pm 0.7 \mathrm{~mm}$ on the right and $7.62 \pm 0.55 \mathrm{~mm}$ of left side respectively.

The comparison between the diameter of the left and right AP didn't show any statistical significance (Hasan et al., 2019). Patel and Singel conducted the similar study in Saurashtra region using 91 Indian skulls. As per their studies $60.4 \%$ cases had larger right jugular foramen and $15.4 \%$ cases had larger left foramen. Further to this they also found that 35.2\% had equal sides on both the sides. In their studies they mentioned that jugular fossa was observed in 38.5\% on the right side. It was on the left side in 14.3\% cases (Patel and Singel, 2007). The studies conducted by Idowu on the Nigerian skulls reports the mean length $13.9 \mathrm{~mm}$ on the right side and $14.11 \mathrm{~mm}$ on the left side. They also report the mean width to be at $10.2 \mathrm{~mm}$ on the right side and $9.2 \mathrm{~mm}$ on the left side on the Nigerian skulls (Idowu, 2004).

\section{CONCLUSION}

Due to the evolutionary process the dissimilarities in the shape, size and compartments of Jugular foramen may exist. Understanding the construction and arrangement of the structures and the morphology within the foramen is crucial in figuring out the position of various formations, from the data available on Jugular foramen, detailed in this study. This understanding will also help the clinicians greatly in discerning the clinical presentations. It will also guide them in the progression of lesions of the jugular foramen and devising the most suitable accessions in a surgery. The inferences from this study can also enable a better understanding of the involvement or the sparing of the neurovascular formations while carrying out the lesions in the jugular foramen. The study can also be instrumental in better assimilation of the images of jugular foramen.

\section{ACKNOWLEDGEMENTS}

We acknowledge the Department of Anatomy for allowing us to use skulls from their collection for our study.

Conflict of Interest: The author declares that there is no conflict of interest in the present study.

\section{REFERENCES}

Abdul Wahab, P. U. et al. (2017) 'Risk Factors for Postoperative Infection Following Single Piece Osteotomy', Journal of maxillofacial and oral surgery, 16(3), pp. 328-332.

Abhinav, R. P. et al. (2019) 'The Patterns and Etiology of Maxillofacial Trauma in South India', Annals of maxillofacial surgery, 9(1), pp. 114-117.

Aggarwal, A. et al. (2012) 'Morphometric Study of the Jugular Foramen in Northwest Indian Population', Journal of Postgraduate Medicine, Education and Research, pp. 165-171. doi: 10.5005/jp-journals-100281038.

Anson, B. J. (1972) 'Critical distances in the middle and inner ear and in the posterior cranial fossa', Transactions - American Academy of Ophthalmology and Otolaryngology. American Academy of Ophthalmology and Otolaryngology, 76(1), pp. 108-129.

Daniels, D. L., Williams, A. L. and Haughton, V. M. (1984) 'Jugular foramen: anatomic and computed tomographic study', American Journal of Roentgenology, pp. 153158. doi: 10.2214/ajr.142.1.153.

Das, S. S., Saluja, S. and Vasudeva, N. (2016) 'Complete morphometric analysis of jugular foramen and its clinical implications', Journal of craniovertebral junction and spine, 7(4), pp. 257-264.

Eapen, B. V., Baig, M. F. and Avinash, S. (2017) 'An Assessment of the Incidence of Prolonged Postoperative Bleeding After Dental Extraction Among Patients on Uninterrupted Low Dose Aspirin Therapy and to Evaluate the Need to Stop Such Medication Prior to Dental Extractions', Journal of maxillofacial and oral surgery, 16(1), pp. 48-52.

Ekinci, N. and Unur, E. (1997) 'Macroscopic and morphometric investigation of the jugular foramen of the human skull', Kaibogaku zasshi. Journal of anatomy, 72(6), pp. 525-529.

Ellis, H. (1989) ‘Gray’s anatomy. 37th ed. P. L. Williams, R. Warwick, M. Dyson, L. H. Bannister. $305 \times 235 \mathrm{~mm}$. Pp. 1598. Illustrated. 1989. Edinburgh: Churchill Livingstone. Ł70.00’, British Journal of Surgery, pp. 1359-1359. doi: 10.1002/bjs.1800761258.

Hasan, D. V. et al. (2019) A Comparative Study of the Anatomy of the Jugular Foramen and Its Variations in Dried Adult Human Skulls in Sri Lankan Population. doi: 10.5281/zenodo.2643093.

Hatiboglu, M. T. and Anil, A. (1992) 'Structural variations in the jugular foramen of the human skull', 
Journal of anatomy, 180 ( Pt 1), pp. 191-196. Idowu, 0. E. (2004) 'The jugular foramen -- a morphometric study', Folia morphologica, 63(4), pp. 419-422.

Jain, M. and Nazar, N. (2018) 'Comparative Evaluation of the Efficacy of Intraligamentary and Supraperiosteal Injections in the Extraction of Maxillary Teeth: A Randomized Controlled Clinical Trial', The journal of contemporary dental practice, 19(9), pp. 1117-1121.

J, P. C. et al. (2018) 'Prevalence and measurement of anterior loop of the mandibular canal using CBCT: A cross sectional study', Clinical implant dentistry and related research, 20(4), pp. 531-534.

Katsuta, T., Rhoton, A. L. and Matsushima, T. (1997) 'The Jugular Foramen: Microsurgical Anatomy and Operative Approaches', Neurosurgery, pp. 149-202. doi: 10.1097/00006123-199707000-00030.

Lopes, P. T. C. et al. (2011) 'Morphometric Analysis of the Greater Palatine Foramen in Dry Southern Brazilian Adult Skulls', International Journal of Morphology, pp. 420-423. doi: 10.4067/s0717-95022011000200019.

Marimuthu, M. et al. (2018) 'Canonical Wnt pathway gene expression and their clinical correlation in oral squamous cell carcinoma', Indian journal of dental research: official publication of Indian Society for Dental Research, 29(3), pp. 291-297.

Matsushima, T. (2015) 'Microsurgical Anatomy of and Surgical Approaches to the Jugular Foramen', Microsurgical Anatomy and Surgery of the Posterior Cranial Fossa, pp. 277-297. doi: 10.1007/978-4-43154183-7_20.

Padget, D. H. (1957) The Development of the Cranial Venous System in Man: From the Viewpoint of Comparative Anatomy. Carnegie Inst.

Patel, M. M. and Singel, T. C. (2007) 'Variations in the structure of the jugular foramen of the human skull in Saurashtra region', Journal of the Anatomical Society of India, 56(2), pp. 34-37.

Patil, S. B. et al. (2017) 'Comparison of Extended Nasolabial Flap Versus Buccal Fat Pad Graft in the Surgical Management of Oral Submucous Fibrosis: A
Prospective Pilot Study', Journal of maxillofacial and oral surgery, 16(3), pp. 312-321.

Ramadorai, A., Ravi, P. and Narayanan, V. (2019) 'Rhinocerebral Mucormycosis: A Prospective Analysis of an Effective Treatment Protocol', Annals of maxillofacial surgery, 9(1), pp. 192-196.

Ramina, R. et al. (2005) 'Tumors of the jugular foramen: diagnosis and management', Neurosurgery, 57(1 Suppl), pp. 59-68; discussion 59-68.

Senthil Kumar, M. S. et al. (2019) 'Inflammatory pseudotumour of the maxillary sinus: clinicopathological report', Oral Surgery, 12(3), pp. 255-259.

Song, M. H. et al. (2008) 'Jugular foramen schwannoma: analysis on its origin and location', Otology \& neurotology: official publication of the American Otological Society, American Neurotology Society [and] European Academy of Otology and Neurotology, 29(3), pp. 387-391.

Sturrock, R. R. (1988) 'Variations in the structure of the jugular foramen of the human skull', Journal of anatomy, 160, pp. 227-230.

Sweta, V. R., Abhinav, R. P. and Ramesh, A. (2019) 'Role of Virtual Reality in Pain Perception of Patients Following the Administration of Local Anesthesia', Annals of maxillofacial surgery, 9(1), pp. 110-113.

Tekdemir, I. et al. (1998) 'The jugular foramen', Surgical Neurology, pp. 557-562. doi: 10.1016/s00903019(98)00048-2.

Vijisha, P., Bilodi, A. K. and Lokeshmaran (2013) 'Morphometric study of jugular foramen in Tamil Nadu region', National Journal of Clinical Anatomy, pp. 071-074. doi: 10.1055/s-0039-3401710.

Wahab, P. U. A. et al. (2018) 'Scalpel Versus Diathermy in Wound Healing After Mucosal Incisions: A SplitMouth Study', Journal of oral and maxillofacial surgery: official journal of the American Association of Oral and Maxillofacial Surgeons, 76(6), pp. 1160-1164.

Wysocki, J. and Sharifi, M. (2006) 'The occurrence, variations and diameter of the human condylar canal in relation to the jugular foramen', Folia morphologica, 65(1), pp. 11-14. 